\title{
As cores e os gêneros da revolução*
}

\author{
Luiz Gustavo Freitas Rossi**
}

\begin{abstract}
Resumo
Este artigo tem por objetivo analisar parte dos romances de Jorge Amado, publicados na década de 1930, à luz dos diálogos que o autor estabeleceu com o debate racial naquele momento, com especial atenção às obras Jubiabá (1935), Mar Morto (1936) e Capitães de Areia (1937). Trata-se, fundamentalmente, de um esforço em ressaltar as possíveis articulações entre as noções de raça, classe social e gênero presente nestas obras, lidas sob uma dupla perspectiva. De um lado, a partir dos sentidos de que Jorge Amado investiu sua produção literária na chave de um romance proletário e, de outro, tendo em vista os tratamentos particulares que dispensou ao seu "material etnográfico" sobre o negro, encontrando neste matéria-prima privilegiada de ficcionalização.
\end{abstract}

Palavras-chave: Jorge Amado, Raça, Classe Social, Gênero.

\footnotetext{
" Recebido para publicação agosto de 2004, aceito outubro de 2004. Este artigo é uma versão ligeiramente modificada do terceiro capítulo de minha dissertação de mestrado - As Cores da Revolução: a literatura de Jorge Amado nos anos 30 - defendida na Unicamp em junho de 2004, sob a orientação de Heloísa Pontes. Gostaria de agradecer a Mariza Corrêa pelo convite em escrever este artigo, assim como pelos comentários feitos na ocasião da defesa de minha dissertação e a Sergio Miceli, também membro da banca, pelas críticas e sugestões formuladas. Deixo aqui registrado meus agradecimentos pela leitura sempre cuidadosa e valiosa de Heloisa Pontes para a construção do artigo. Por fim, devo mencionar a paciência e o interesse de Marilia d'Ottaviano Giesbrecht e Mariana Françoso, com as quais este texto foi constantemente discutido.

** Doutorando em Ciências Sociais, IFCH-Unicamp, Campinas-SP, Brasil. lgfrossi@hotmail.com
} 
As cores e os gêneros da revolução

The Colors and Genders of Revolution

\begin{abstract}
The aim of this paper is to analyze part of Jorge Amado's novels that were published in the 1930's in the context of the debates about race in which the author took part. Three books are the center of this analysis, namely Jubiabá (1935), Mar Morto (1936) and Capitães de Areia (1937). It focuses on the possible articulations between the notions of race, class and gender in these books, from two different points of view. On one hand, it studies these books paying attention to what Jorge Amado himself considered a "proletarian novel" - for this was one of his main concerns when writing his literature. On the other hand, it examines how the author used his "ethnographic data" about black people, since he elected them as the principal subjects of his fiction.
\end{abstract}

Key Words: Jorge Amado, Race, Class, Gender. 
Luiz Gustavo Freitas Rossi

\section{Introdução}

Falecido em 6 de agosto de 2001, Jorge Amado consolidou na história da literatura brasileira uma das carreiras mais bem sucedidas de nosso mercado editorial. Suas vasta obra, navegando pelos diversos gêneros literários, entre eles o romance, a biografia $e$ os textos políticos, nos conduz a números assombrosos de consumo, cujas estimativas podem chegar ao número de 30 milhões de exemplares. ${ }^{1}$ Amplamente lido e consumido, Jorge Amado (1912-2001) transformou-se não apenas em um fenômeno de vendas, no Brasil e no mundo, como também ofereceu um repertório amplo de temas, paisagens, personagens $e$ linguagens constantemente acionados como representativos da sociedade e da cultura brasileiras. Um escritor que teria conseguido em seus romances apreender de maneira ímpar, numa espécie de drágea concentrada, aquela "essência" que nos define enquanto povo e Nação: a mestiçagem cultural $e$ biológica. Ou então, como gostam de afirmar alguns de seus intérpretes e admiradores: "fez de seus livros um hino à cultura negra e mestiça de nosso país e à miscigenação que nos faz ser o que somos". ${ }^{2}$

Entretanto, aos olhos de hoje, se a figura de Jorge Amado nos remete a uma idéia quase que imediata de consagração nas letras nacionais, assim como dessas noções e julgamentos bastante

1 Cf. GoldsteIn, Ilana. Literatura e Identidade Nacional: o Brasil best-seller de Jorge Amado. Dissertação de Mestrado, São Paulo, FFLCH/Usp, 2000, pp.1011. Ainda, segundo Goldstein, números fornecidos pela editora Record relativos às vendas entre os anos de 1975 e 2000, os livros de maiores vendagens seriam: Capitães da Areia (4,3 milhões); Quincas Berro D'água (3,2 milhões); Gabriela, Cravo e Canela (2 milhões); Tocaia Grande (1,7 milhões) e Mar Morto (1,5 milhões). O restante de seus livros oscilando em torno de 150 a 800 mil exemplares, cada um.

2 Olinto, Antonio. A Comédia dos Orixás. In: Rollemberg, Vera. (org.) Simpósio Internacional de Estudos sobre Jorge Amado. Salvador, FCJA/EdUFBA, 1999, p.158. 
As cores e os gêneros da revolução

sedimentados acerca de totalidade de sua obra - nosso escritor da "miscigenação" e das mulatas cheirando à "cravo e canela" - a análise da questão racial na sua produção na década de 1930 nos lança a um quadro sensivelmente distinto de referências $e$ sentidos, através dos quais a "raça" foi incorporada e abordada na sua prática literária. Desta forma, centrado na análise de sua obra dos anos de 1930, especialmente seus romances Jubiabá (1935), Mar Morto (1936) e Capitães da Areia (1937), o objetivo deste artigo é investigar os tratamentos que Jorge Amado dispensou à questão racial, ressaltando as possíveis articulações entre as noções de raça, classe social e gênero presentes nestas obras. ${ }^{3}$

Para tanto, antes de mais nada, é preciso prestarmos atenção aos significados que Jorge Amado investiu nesta parte de sua produção mediante a prática de uma chamada literatura proletária ${ }^{4}$, mostrando como suas formulações acerca do caráter, função e estilo dessa modalidade de romance tornaram-se decisivas para que o negro aparecesse como um material

3 Além dos três romances já mencionados no texto, Jorge Amado publicou anteriormente outros três durante a década de 1930: País do Carnaval (1931), Cacau (1933) e Suor (1934). Entretanto, para uma análise mais pontual da questão racial, Jubiabá, Mar Morto e Capitães da Areia são aqueles que conformam um material de maior rendimento analítico, na medida em que diferente daqueles três primeiros - tanto os negros quanto a cultura afrobrasileira, efetivamente, foram incorporados como temas relevantes e centrais na construção dos enredos e personagens.

4 Alfredo Wagner Berno de Almeida, autor de um brilhante estudo sobre a trajetória intelectual de Jorge Amado, chama a atenção sobre a importância de se retomar esta discussão sobre uma literatura proletária na década de 1930, já que a expressão acabou "diluída" na história literária por denominações $e$ classificações como romance social, documentário, ou mesmo "do Nordeste". Como aponta o autor, em uma de suas notas: "trata-se de uma lacuna grave nas obras de cunho classificatório. Antes de uma mera troca ou substituição de expressões está em jogo a ignorância de uma das mais notáveis polêmicas a respeito de uma teoria literária, que caracterizou a produção literária na primeira metade da década de 1930". Cf. AlmEIDA, Alfredo Wagner Berno de. Jorge Amado: política e literatura: um estudo sobre a trajetória intelectual de Jorge Amado. Rio de Janeiro, Campus, 1979, p.128. 
privilegiado de ficcionalização. Isto, certamente, com implicações para apreendermos os modos como o escritor dialogou através destas obras com alguns dos personagens que vinham retomando os estudos sobre o negro no Brasil, tais como Édison Carneiro (1912-1972), Arthur Ramos (1903-1949) e Gilberto Freyre (19011987).

Minha preocupação em retomar estas discussões em torno de uma literatura proletária e o diálogo de Amado com os estudiosos "da raça" deve-se ao cuidado de não forjar uma interpretação "desencarnada" de sua obra ficcional. Isto porque, a abordagem que o romancista dispensou ao negro somente ganha sentido quando levamos em conta as categorias com as quais o autor concebeu e realizou a sua arte. Dito de outra forma, trata-se de buscar uma historicidade à atividade intelectual e literária de Jorge Amado, evidenciando a relevância desses debates literário $e$ antropológico para uma análise mais ajustada de sua obra aos termos da época, sem com isto fazer da história e do contexto em que foram gestadas uma "camisa-de-força" que tudo explica ou, simplesmente, reflete na dimensão literária e simbólica que nos interessa. Ou seja,

Admitir (...) que é a análise histórica que permite compreender as condições de "compreensão", apropriação simbólica, real ou fictícia, de um objeto simbólico que pode acompanhar-se dessa forma particular de fruição que chamamos estética. Isso sem fazer do conhecimento da verdade histórica a condição e a medida do prazer estético. ${ }^{5}$

\section{Literatura proletária e a questão racial}

Em 1933, ano em que Jorge Amado publicou seu segundo romance, Cacau, uma nota explicativa veio jogar luz ao seu recente alinhamento político e estético às fileiras da militância comunista:

${ }^{5}$ Bourdieu, Pierre. As Regras da Arte. São Paulo, Cia das Letras, 1996, p.365. 
As cores e os gêneros da revolução

Tentei contar neste livro, com um mínimo de literatura para um máximo de honestidade, a vida dos trabalhadores das fazendas de cacau no sul da Bahia. Será um romance proletário? ${ }^{6}$

Ora, que sentido faz esta "explicação" do romancista no âmbito dos debates literários que se consolidaram àquela época? Quais os valores distintivos, capazes de definir, ou não, Cacau como um romance proletário? E por fim, qual a importância desse posicionamento político-literário para a apreensão do debate racial?

Uma rápida observação dos debates literários da década de 1930 mostra-se reveladora de como parcela significativa dos romances foram avaliados por critérios em que, para retomar uma expressão de Octávio de Faria (1908-1980), o "essencial não pode ser estilo ou construção". ${ }^{7}$ Tratava-se de um momento em que os excessos de preocupações formais poderiam significar uma mistificação da prática literária que, nas palavras de Antonio Candido, "consistia em procurar uma atividade de análise e crítica em face do que se chamava incansavelmente de "realidade brasileira". 8 Assim, foi na busca deste "Brasil real" que o romance, entendido pelas suas qualidades de depoimento, documento e/ou fotografia do mundo social, teria encontrado na

${ }^{6}$ AmAdO, Jorge. Cacau. Rio de Janeiro, Record, 1987, p.8. (os destaques são meus).

7 FARIA, Octávio de. País do Carnaval. In: Jorge Amado: 30 anos de literatura. São Paulo, Martins, 1961 [1931], p.61. O acompanhamento da recepção crítica não apenas de País do Carnaval, livro que o comentário de Octávio de Faria se refere, mas também de seus livros seguintes - Cacau, Suor e Jubiabá, por exemplo - multiplicariam o material em que poderíamos encontrar maiores exemplos destes parâmetros da crítica à época. Parte significativa desta recepção crítica encontra-se analisada em ALmEIDA, A. W. B. de. Jorge Amado: política e literatura... Op. cit.

8 CÂNDIDO, Antonio. A revolução de 30 e a cultura. In: A Educação pela Noite e Outros Ensaios. São Paulo, Ática, 1989, p.189. 
produção sociológica um repertório temático e expressivo. ${ }^{9}$ Separadas por linhas bastante tênues e porosas, literatura $e$ ciências sociais pareciam conviver, como observou Gilberto Freyre, sob uma intensa

dificuldade de se fixarem hoje fronteiras nítidas ou de se estabelecerem limites absolutos, entre as chamadas belasletras e as outras, que devem ser as feias. Que pelo menos não são as belas. A sociologia, a economia, a história, a biografia. O sexo masculino da literatura. O sexo bruto, forte e talvez feio da literatura (...) Intelectualmente, como socialmente, estamos numa época em que o masculino $e$ feminino tendem a um tipo único". ${ }^{10}$

Ainda que Freyre apontasse para o aspecto positivo desta aproximação, havia um perigo eminente: "o do romance deixar de ser belas-letras - pela própria incompetência artística do autor para tornar-se má sociologia - pela maior incompetência científica do mesmo autor". ${ }^{11}$ Ao atribuir gêneros específicos a cada um

9 Cf. Oliveira, Lúcia Lippi. O romance e o pensamento político nos anos 30. In: Portela, Eduardo. (org.) O Romance de 30 no Nordeste. Fortaleza, PROED, 1983.

${ }^{10}$ FREYRE, Gilberto. Sociologia e Literatura. Boletim de Ariel, $\mathrm{n}^{\circ} 4$, novembro de 1936, p.16.

${ }^{11}$ ID., IB., p.17. A formulação de Gilberto Freyre, ao qualificar as categorias feminino e masculino - respectivamente como o belo e delicado e forte e bruto demarca numa linha de contigüidade os espaços, símbolos e sentimentos socialmente atribuídos às relações de gênero no Brasil daquela época. Mariza Corrêa, não aleatoriamente, mostra em Antropólogas \& Antropologia como as atuações das pesquisadoras Heloísa Alberto Torres, Leolinda Daltro e Emília Snethlage acabam por gerar representações ambíguas quando transformadas em personagens de ficção, justamente, na medida em que buscaram ocupar o espaço da produção científica nas três primeiras décadas do século XX. Neste sentido, encontramos o mesmo perigo que "estava na poluição de fronteiras entre o masculino e o feminino, pela ocupação de lugares socialmente, explícita ou implicitamente, destinados a uma dessas categorias, mas não à outra". Cf. CORRÊA, Mariza. Antropólogas \& Antropologia. Belo Horizonte, Ed. UFMG, 2003, p.152. 
As cores e os gêneros da revolução

destes tipos de bens simbólicos - a literatura como feminino $e$ as ciências sociais como masculino - o sociólogo pernambucano revela um aspecto caro não apenas para os romancistas, mas também para os espaços e veículos de avaliação literária nos anos de 1930: a "tendência" a um produto simbólico híbrido, misto de sociologia com literatura, "perigosamente" a meio caminho entre o masculino e o feminino. Este clima de permuta simbólica entre a literatura e a sociologia, menos que o resultado de acasos ou das excentricidades de literatos e cientistas sociais em buscar recursos e técnicas que transbordavam os limites de seus ofícios, deve ser visto no contexto amplo dos conflitos que se colocavam no processo de autonomização de cada um deles.

À medida que a literatura acompanha o processo de autonomização característica do campo intelectual, ela abandona cada vez mais o concurso dos bacharéis e do conhecimento jurídico (...) Os produtores literários, empenhados em firmar o reconhecimento de sua autonomia e de sua própria intervenção no campo de poder, voltam-se para as ciências sociais, especialmente para a sociologia, amparando com suas "técnicas" a fabricação do romance. A ocorrência é registrada justamente no momento em que as ciências sociais, carecendo de instituições apropriadas e produtores especializados buscavam também sua afirmação. ${ }^{12}$

O "tom de reportagem social e quase sociológica; a (...) qualidade de documento" 13 apresentavam-se, então, como chaves

\footnotetext{
${ }^{12}$ AlmeidA, A. W. B. de. Jorge Amado: política e literatura... Op. cit., pp.80-81, (destaques do autor).

${ }^{13}$ FREYRE, G. Sociologia e Literatura. Op.cit., p.15. Um artigo de Jorge Amado mostrava-se bastante afinado a este modo de entender e conceber o romance: "O sentido de documento, de grito, é sem dúvida a coisa que surge mais clara no novo romance brasileiro (...) Viram esse mundo ignorado que é o Brasil. E o Brasil é um grito, um pedido de socorro". AMADO, Jorge. Apontamentos sobre o moderno romance brasileiro. Lanterna Verde, n 1 , maio de 1934, p.48 (ênfases do autor).
} 
de leitura privilegiadas, através das quais parte da literatura de ficção buscou ser lida e avaliada neste ambiente. Assim, o mínimo de literatura para um máximo de honestidade preconizado por Jorge Amado em sua nota explicativa a Cacau mostrava-se bastante ajustado aos critérios que se colocavam à produção literária à época, deixando poucas referências para entendermos o que Amado quis dizer com "romance proletário". Ainda, se levarmos a sério esta aproximação entre literatura e ciências sociais, há um aspecto no caso de Jorge Amado que parece adensar suas relações com a prática sociológica e, porque não, antropológica: a coleta de dados e materiais para a criação de seus romances. ${ }^{14}$ Mesmo residindo no Rio de Janeiro a partir de junho de 1930, Jorge Amado realizou uma série de viagens por "cidadezinhas" no Nordeste, onde teria encontrado e organizado material para temas, ambientes e personagens de seus romances.

Para um sujeito como eu que não tem nenhuma imaginação, o romance tem que ser tirado da vida real. A idéia do romance aparece em mim vagamente, um dia. Uma frase, um tipo, qualquer coisa me lembra o romance. (...) Aos poucos a coisa vai amadurecendo, um dia existe um plano. Começo então a recolher material, o plano vai se transformando à proporção que o material vai aparecendo. Quando já estou com as gavetas cheias de material e o cérebro cheio de personagens ainda em

\footnotetext{
${ }^{14}$ A prática de "coleta de dados", ao que tudo indica, não constituiu uma exclusividade do processo criativo de Jorge Amado. Como mostra José Tavares Correia de Lira, o interesse e a busca de materiais "folclóricos e populares" fez parte dos interesses de uma série de escritores e artistas, tais como Ascenso Ferreira (1865-1965), Cícero Dias (1907-2003) e José Lins do Rego (19011957). Este último, junto com Gilberto Freyre eram os principais "guias" das coisas e lugares folclóricos do escritor Mário de Andrade (1883-1945), na ocasião de sua viagem etnográfica pelos estados nordestinos. Cf. LIRA, José Tavares Correia de. Naufrágio e galanteio: viagem, cultura e cidades em Mário de Andrade e Gilberto Freyre. Texto apresentado no Encontro anual da ANPOCS, outubro de 2003.
} 
As cores e os gêneros da revolução

estado de gestação, organizo uma espécie de plano definitivo (...) Os personagens é que dirigem o livro. ${ }^{15}$

A falta de imaginação é ressaltada por Amado, ao mesmo tempo que procura colocar os personagens como aqueles que ditam as regras, transferindo o ato de criação à forças externas, à realidade, ao dado, no qual o autor é apenas um médium que as capta e dá forma literária. Entretanto, não é por qualquer realidade que Jorge Amado se interessou, seu olhar buscou apreender principalmente o universo existencial dos miseráveis $e$ excluídos, das classes trabalhadoras, no sentido de incorporá-los na construção temática e formal de sua ficção. Como Antonio Candido observou certa vez, comentando a originalidade destes romancistas "de 30" - entre eles Jorge Amado, José Lins do Rego (1901-1957), Graciliano Ramos (1892-1953) e Rachel de Queiroz (1910-2003) - houve uma "ida ao povo" que os singularizaram na procura de uma literatura e um Brasil autêntico, inaugurando "um movimento de integração, ao patrimônio de nossa cultura, da sensibilidade e da existência do povo (...) a reclamar o seu lugar na nacionalidade e na arte". ${ }^{16}$

À luz destas aproximações das linguagens e das técnicas sociológicas e antropológicas no "trabalho de campo" amadiano, da incorporação da linguagem popular, sua oralidade e do compromisso tácito e documental com a realidade é que o alinhamento de Jorge Amado a uma arte militante, a chamada literatura proletária, deve ser entendido e problematizado. Com isto, poderemos então conectar o processo criativo do escritor aos

\footnotetext{
${ }^{15}$ AmADO, Jorge. Personagens. Lanterna Verde, n 2, fevereiro de 1935, p.93. Neste mesmo artigo há outras referências ao processo de coleta de material para a composição de suas obras, como por exemplo: "Agora mesmo estou amadurecendo um plano de livro sobre negros (...) Desde esse ano recolho material para esse livro". Idem, ibidem. Sete meses depois, em setembro de 1935, Jorge Amado publicou Jubiabá.

${ }^{16}$ CÂNDIDO, Antonio. Poesia, documento, história. In: Brigada Ligeira. São Paulo, Unesp, 1992 [1945], p.46.
} 
significados deste gênero literário para, finalmente, pontuarmos o lugar onde o negro e o debate racial serão alocados no âmbito de sua prática romanesca.

Os debates travados sobre as possibilidades $e$ as circunstâncias de uma "autêntica" arte proletária na década de 1930 mostraram-se em geral bastante heterogêneos e, talvez, não aleatoriamente o próprio Jorge Amado expressasse sua dúvida - "Será um romance proletário?" - acerca da pertinência deste formato em Cacau. Se prestarmos atenção em algumas intervenções do escritor podemos apreender um horizonte de referências sobre que tipo de arte ele está pensando, quando se indaga a respeito da literatura proletária:

é uma literatura de luta e revolta. E de movimento de massa. Sem heróis, nem heróis de primeiro plano (...) fixando vidas miseráveis sem piedade mas com revolta. É mais crônica e panfleto (...) do que romance no sentido burguês [fazendo] do leitor um inimigo da outra classe. ${ }^{17}$

Deste modo, o escritor proletário deveria, antes de tudo, provocar a revolta daqueles que lêem sua obra e incitar a revolta a partir de um texto indigesto. Trazendo para o plano narrativo as experiências e condições de vida desta classe emergente no Brasil, Jorge Amado concebeu esta modalidade literária como um instrumento de transição e acirramento de conflitos, formulada nos termos de um "panfleto" doutrinário para a prática revolucionária. Uma literatura "anti-burguesa" 18 capaz de

${ }^{17}$ AmADO, Jorge. P.S. Boletim de Ariel, n¹1, agosto de 1933, p.292.

18 "A arte proletária é, pois, a arte anti-burguesa do período da luta de classes. Do período de contradições onde nos achamos". Cf. GuIMARÃES, Alberto Passos. A propósito de um romance. Boletim de Ariel. n ${ }^{\circ} 11$, agosto de 1933, p.288. Ainda, poderíamos mobilizar uma série de textos onde se discutiu a "literatura proletária", se acompanhássemos parte da recepção crítica dos romances de Jorge Amado: "primeira tentativa séria de romance proletário no Brasil (...) É um livro de revolta". Cf. CostAS, Dias da. Cacau. Boletim de Ariel. $n^{\circ} 2$, novembro de 1933, p.36. Ou então, "conseguir revoltar sobretudo, é o maior mérito do 
As cores e os gêneros da revolução

expressar o momento de efervescência política e ideológica do comunismo e o drama das coletividades e das massas excluídas:

Hoje, era do comunismo e do arranha-céu, da habitação coletiva, o romance tende para a supressão do herói, do personagem (...) $\mathrm{O}$ drama de um único sujeito não interessa. Interessa o drama coletivo, o drama da massa, da classe, da multidão. Tudo tem importância decisiva. $\mathrm{O}$ mínimo detalhe, a personagem mais sumida. ${ }^{19}$

O romance proletário amadiano dos anos de 1930 forjou um sentido de massa, povo e popular pregado ao pertencimento à classe proletária, procurando alargar este pertencimento a todos aqueles que, de alguma maneira, encontravam-se numa situação de exclusão e subordinação e possuíam, potencialmente, capacidade de subverter a ordem social. Assim, em larga medida, foi na formulação de sua literatura proletária, concebida nos termos de um texto estilisticamente ajustado para que os dramas das coletividades fossem expressos, que Jorge Amado encontrou no negro e na questão racial temas privilegiados para solucionar, dar forma, "cor política" 20 e "gênero" aos seus romances Jubiabá, Mar Morto e Capitães da Areia. Isto aparece mais nítido, quando

intelectual engajado. E este Jorge Amado possue". Cf. JUREMA, Aderbal. O novo livro de Jorge Amado. Boletim de Ariel, n 12, setembro de 1934, p.331.

${ }^{19}$ AMADO, Jorge. Apontamentos... Op.cit, pp.49-50. Em particular, no romance Suor podemos encontrar uma série de recursos instigantes através dos quais Jorge Amado expressa a idéia de uma coletividade. Vale destacar o tratamento que o escritor dispensa ao corpo, conformando sempre uma matéria disforme e grotesca, como um recurso que almeja criar personagens "borrados" $e$ desprovidos de individualidade. Cf. Rossi, L. G. F. As Cores da Revolução... Op. cit., em particular o segundo capítulo - "Imagens da multidão e o corpo dos condenados".

20 "Sou dos que não acreditam na 'arte pela arte', no 'romance impolítico' (...) O que não se admite são os que querem agradar a todo mundo, a Deus e ao Diabo, se colocando na cômoda posição de romancistas puros e sem cor política". AMADO, J. Apontamentos... Op. cit., p.51 (destaque meu). 
observamos a comunicação que o escritor apresentou no $1^{\circ}$ Congresso Afro-Brasileiro (1934), em Recife. O escritor diria:

Na Bahia o elemento popular é o negro e o mulato, as religiões africanas continuam a ter uma decisiva influência na massa, $e$ assim sua literatura popular não pode deixar de ser diretamente influenciada pelo negro (...) mesmo aquilo que não é negro nestas coleções, é escolhido pelo gosto negro do público que compra e lê. ${ }^{21}$

No esteio de seus posicionamentos político e estético, nos quais pareceu haver uma justaposição entre aquilo que o escritor entendeu por popular e proletário - como categorias intercambiáveis e ajustáveis uma a outra - o negro e o "racial" apresentaram-se como uma espécie de "objeto-tema" privilegiado, capaz de expressar as aspirações literárias e militante-partidária do escritor. No cruzamento de sentidos entre classe, popular e raça, o negro encarnou a figura do oprimido por excelência: dupla marca de sua condição étnica e social $e$, neste sentido, apostando na incorporação da primeira pela última como solução dos conflitos de ambas. Entretanto, se por um lado foi a figura do negro, assim como sua cultura, que encarnou um ideal subversivo da ordem social neste projeto literário, por outro, foi também na figura da mulher que o romancista baiano teria encontrado um potencial homólogo de subversividade, na medida em que, incorporada ao universo negro do romance, empreende um deslocamento dos espaços femininos para ocupar aqueles, até então, exclusivamente masculinos.

\section{Cores que circulam e os gêneros da revolução}

Os romances Jubiabá, Mar Morto e Capitães da Areia constituem, podemos dizer, os resultados significativos de uma

${ }^{21}$ ID. "Biblioteca do povo" e "Coleção Moderna". In: FrEYRE, G. et.alii. Estudos Afro-Brasileiros, Recife, Massangana, 1988, pp.262-63. (ênfases minhas) 
As cores e os gêneros da revolução

importante inflexão na produção literária de Jorge Amado. Tratase de um momento em que o escritor assinalou não apenas seu interesse pela "raça negra", como também redimensionou o lugar que esta raça ocupou em suas obras, quando vistas à luz de seus empreendimentos anteriores. Ou seja, o negro passou de parte de uma classe proletária para ser a própria expressão desta. De modo muito rápido e superficial, poderíamos dizer que Cacau e Suor, inflamados por um estilo de urgência e pressa revolucionária, foram concebidos em torno de uma rígida polarização do mundo social - aquela entre burgueses e proletários - a partir da qual o negro surgiu quase que imediata e "naturalmente" submerso a uma identidade proletária, acachapando de uma só vez suas especificidades históricas, sociais e culturais nas malhas de uma multidão deformada e destituída de paticularidades.

Neste sentido, com Jubiabá, Mar Morto e Capitães da Areia percebemos, então, como o romancista efetua sensíveis "inversões" desta lógica "proletarizadora" do mundo social para trilhar um caminho "racializante" do proletariado brasileiro. Ainda, a atenção mais circunstanciada que Jorge Amado dispensou às dimensões culturais e simbólicas do negro brasileiro, acabou por gerar algumas implicações de ordem estilística que parecem relativizar - ou ao menos atenuar - a dualidade rígida $e$ pragmática com que se debruçou para fazer sua literatura e pensar a realidade social como um todo. ${ }^{22}$

${ }^{22}$ Certamente, esta incorporação da questão racial em sua obra, a partir de Jubiabá, deve ser vista num contexto amplo de "aprendizagem" que Jorge Amado teria desfrutado, principalmente, entre os anos de 1934 e 1937. Destaque merece a participação de Jorge Amado nos dois Congressos Afro-brasileiros de 1934 e 1937, respectivamente em Recife e Salvador, mas também o interesse com que acompanhou o boom editorial dos estudos africanistas no Brasil. Tal interesse pode ser acompanhado não apenas na correspondência de Édison Carneiro à Arthur Ramos, na qual Jorge Amado aparece como uma figura de destaque, inclusive como um incentivador de Carneiro para se lançar nos estudos etnográfico, mas também como uma espécie de "mediador" entre este último e Arthur Ramos. Cf. LimA, Vivaldo Costa \& OliveIRA, Waldir Freitas de. Cartas de Édison Carneiro a Arthur Ramos. São Paulo, Corrupio, 1987. Em uma outra 
Publicado em 1935, um ano após a realização do Primeiro Congresso Afro-Brasileiro em Recife - congresso em que, como já dito, Jorge Amado foi convidado a participar, apresentando uma comunicação sobre a literatura de cordel na Bahia - Jubiabá inaugurou, para alguns, a aparição de um herói negro na literatura brasileira. Considerado como "magnífico e assombroso" ${ }^{23}$, nas palavras de Albert Camus ou, como classificou Oswald de Andrade, "uma ilíada negra" ${ }^{24}$, este romance trata da trajetória do personagem Antônio Balduíno, recuperando suas experiências desde os tempos de sua infância no morro do Capa-Negro até sua fase adulta como estivador no porto de Salvador. Menino órfão, criado por sua tia Luísa, vendedora de mingau no centro da cidade, Balduíno tem como educação os acasos da vida $e$ as histórias contadas pelo pai-de-santo Jubiabá, com as quais aprende a fantasiar seu futuro, inspirado nos feitos lendários de Zumbi, Lampião e dos antigos escravos fugidos que morreram lutando para serem livres. Com o enlouquecimento da tia, "desce" para a cidade, onde passa a morar na casa de um comerciante português. Ali, aprende a ler e escrever, e descobre a paixão por Lindinalva, filha do comerciante, que o acompanhará por todo o romance. Entretanto, em função das intrigas da empregada da casa, Baldo foge para as ruas, onde passa a mendigar na companhia de outras crianças. A partir de então, sua trajetória será marcada pelas mais diversas atividades: lutador, malandro, artista de circo, trabalhador rural, até o momento que se emprega

frente, podemos flagrar Jorge Amado comentando e resenhando os trabalhos de Carneiro e Ramos. Cf. AMADO, J. Dois Ensaístas. Boletim de Ariel, n 9, janeiro de 1933 e O jovem Feiticeiro. Boletim de Ariel, n³ 3, dezembro de 1936.

${ }^{23}$ CAmus, Albert. Sobre Jubiabá. In: RAILLARD, Alice. Conversando com Jorge Amado. Rio de Janeiro, Record, 1991 [1939], p.120.

${ }^{24}$ AndRADE, Oswald de. Fraternidade de Jorge Amado. In: RaILlaRD, A. Conversando... Op.cit, p.122. 
As cores e os gêneros da revolução

no porto, descobrindo a greve e adquirindo uma nova perspectiva de conceber o mundo.

Meu interesse, de saída, é chamar a atenção para um tratamento narrativo em Jubiabá, que acredito estar intimamente ligado à apropriação que Jorge Amado efetuou dos elementos da cultura afro-brasileira: trata-se de uma postura estilística que confere uma nova maneira de trabalhar com as distintas temporalidades presentes na narrativa. Passado, presente e futuro serão tomados integradamente para compreendermos a trajetória de Balduíno e a argumentação interna que condiciona suas ações. Procedimento um tanto incomum, se tomarmos como parâmetro os seus três primeiros romances que, guardando suas devidas particularidades, expressavam uma certa aversão do autor ao tratamento igualitário destes três tempos. Em geral, focava momentos $e$ ambientes bastante precisos nos quais o passado $e$ mesmo o futuro tendiam a aparecer obscurecidos ou colocados em suspenso no enredo, em nome de um pretenso "objetivismo fotográfico" do tempo presente em seus romances. ${ }^{25}$

Ainda, a fragmentação narrativa bastante acentuada em Cacau e Suor foi abandonada. Em Jubiabá, Jorge Amado valeuse de um outro formato que dialogava com a tradição folhetinesca, por exemplo, a linearidade narrativa, entrecortada por casos de amores fracassados e desfechos melodramáticos; assim como a forte presença do sobrenatural e a marcante sede de justiça do herói. Isto, arquitetado em meio aos recursos já presentes em suas obras anteriores, como as simplificações maniqueístas e personagens de baixa densidade introspectiva, conforma uma obra de fácil comunicabilidade para reafirmar certos objetivos do escritor, "de dotar seu texto de um efetivo alcance social". ${ }^{26}$

${ }^{25}$ Para uma discussão dos partidos narrativos adotados por Jorge Amado em seus três primeiros romances, conferir o trabalho de DUARTE, Eduardo de Assis. Jorge Amado: romance em tempo de utopia. Rio de Janeiro/Natal, Record/UFRN, 1996

${ }^{26}$ ID., IB., p. 92. 
A leitura de Jubiabá permite entrever como a importância das dimensões simbólicas dos negros, racialmente expressadas, exigiu de Jorge Amado uma outra estrutura narrativa no sentido de dar conta do repertório cultural, do qual Balduíno é depositário $e$, ao mesmo tempo, conduzi-lo à militância política. Articulado a este ponto, acredito que a discussão entre os modos como raça e classe social foram abordados em Jubiabá deve ser formulada a partir de outro enfoque, que não o total $e$ absoluto enquadramento da primeira pela última. Como se a perspectiva de classe, a militância ou o determinismo econômico a qual Balduíno se vê envolvido, simplesmente, o fizesse abandonar de forma integral as noções raciais como chave de compreensão do mundo. Até porque, como veremos, é na greve que Balduíno vislumbra a possibilidade de resignificar o mítico e o lendário da cultura afro-brasileira, "politizando-a" e, dessa forma, incorporando-a ao universo da luta e da consciência de classe.

Educado "solto no morro", ouvindo as histórias contadas pela tia e pelo pai-de-santo Jubiabá, Balduíno cursava esta "única escola que ele e as outras crianças do morro possuíam". ${ }^{27}$ Através dos "causos" lendários de escravos fugidos, cangaceiros valentes e justiceiros e da figura heróica de seu pai - que "apenas sabia que se chamara Valentim, que fora jagunço de Antônio Conselheiro (...) e cachaceiro como ele só..." 28 - Baldo rapidamente deixou de seguir a "única tradição" que ainda valia para os "negros" $e$ "mulatos" do morro. A "tradição da escravidão ao senhor branco e rico". ${ }^{29}$ Assim, nosso personagem, ouvindo e aprendendo estas histórias, desde cedo

resolveu ser do número dos livres (...) Foi no morro do Capa-Negro que Antônio Balduíno resolvera lutar. Tudo o que fez depois foi devido às histórias que ouviu nas noites

\footnotetext{
${ }^{27}$ AMADO, J. Jubiabá. $57^{\text {a }}$ ed, Rio de Janeiro, Record, 2000, p.21.

${ }^{28}$ ID., IB., p.9.

${ }^{29}$ ID., IB., p.26.
} 
As cores e os gêneros da revolução

de lua na porta de sua tia. Aquelas histórias, aquelas cantigas tinham sido feitas para mostrar aos homens o exemplo dos que se revoltaram. Mas os homens não compreendiam ou já estavam muito escravizados. Porém alguns ouviam e entendiam. Antônio Balduíno foi destes que entenderam. ${ }^{30}$

Em poucas palavras, em um só fôlego, o narrador prenuncia a motivação central que condicionará todas as ações de Balduíno: não ser escravo. A recusa visceral de Balduíno é ponto de partida de uma trajetória que será construída como uma incessante preparação de cenários e situações para que nosso herói seja testado e a "profecia" primeva seja cumprida: ser livre. O lendário e o mítico fornecem as chaves para que Balduíno, a partir deste momento, seja conduzido a um futuro, que se não sabemos exatamente como será, temos a certeza de que "ele não ia ser escravo" "31. Para tanto, a cidade é o espaço da provação do herói. E Baldo, ainda criança, já parece pressentir que nela vão se travar os seus mais intensos dramas e aprendizados:

De noite não havia brinquedo que o arrancasse da contemplação das luzes que se ascendiam na cidade tão próxima e tão longínqua (...) esperava com ansiedade de amante que as luzes se acendessem (...) parecia um homem esperando a fêmea (...) Seu coração batia com mais força (...) Ele ficava ouvindo os sons confusos (...) Ficava se imaginando homem feito, vivendo na vida apressada dos homens, lutando a luta de cada dia. ${ }^{32}$

Assim, vemos delinear em sua infância no morro não só o sentido que orquestrará sua existência - fugir da "escravidão das

\footnotetext{
${ }^{30}$ ID., IB. (destaques meus).

${ }^{31}$ ID., IB., p.33.

32 ID., IB., pp.7-8.
} 
fábricas, do campo e dos ofícios proletários"33 -, mas também o palco em que travar-se-á esta fuga: a cidade dos homens "apressados" e das luzes elétricas, que chega a despertar em Balduíno desejos sexuais, tamanho o seu poder de sedução. Deste modo, em Jubiabá, morro e cidade marcam espacialmente uma polaridade, a partir da qual algumas outras serão exploradas: respectivamente, opressão/liberdade; raça e cor/classe e proletário. $\mathrm{O}$ morro sinaliza os elementos de um passado narrativo, mítico e ancestral, no qual o personagem constrói sua identidade racial $e$ rebelde, $e$ a cidade aponta para o futuro da narrativa $e$ sua destinação social, que para ela se dirige. ${ }^{34}$

Retirado de seu lugar de origem após o súbito enlouquecimento da tia, Baldo passa a residir na Travessa Zumbi dos Palmares. Na casa do comerciante Pereira, que "até o colocou na escola pública" 35 , o menino aprende o suficiente para ler e escrever. Entretanto, acostumado à infância livre e travessa do morro, logo é expulso. Sua única escola passa a ser as visitas de Zé Camarão, conhecido malandro do morro que lhe dava aulas de violão, e do velho Jubiabá que, inclusive, ensinou ao menino a história do homem que dava nome à travessa onde morava: "Zumbi (...) Ele foi daí em diante seu herói predileto". ${ }^{36}$ Mesmo quando lançado no espaço urbano, longe dos "seus iguais", Balduíno mantém na figura do pai-de-santo Jubiabá e, com isto, o manancial cultural do qual ele é símbolo e metáfora, sua referência primeira na construção de uma identidade e mitologia próprias.

Assim, é o sentido de raça, "de raça oprimida [que] adquirira à custa das histórias do morro", que leva Balduíno a fugir da casa do comerciante, depois de ser acusado pela

\footnotetext{
${ }^{33}$ ID., IB., p.21.

${ }^{34}$ Cf. CUNHA, Eneida Leal. Jubiabá: leitura em duas vertentes. In: FRAGA, M. (org.) Bahia: a cidade de Jorge Amado. Op.cit., em especial, pp.126-27.

${ }^{35}$ AMADO, J. Jubiabá. Op.cit., p.47.

${ }^{36}$ ID., IB., p.50.
} 
As cores e os gêneros da revolução

empregada racista da casa de olhar maliciosamente para a filha do português, Lindinalva. Toda a benevolência do "senhor" vê-se repentinamente pulverizada pela possibilidade do negro manchar com suas mãos "safadas" a doce e angelical filha. E neste dia,

apanhou uma surra medonha (...) não era só o corpo que doía. Doía-lhe o coração porque não tinham acreditado nele. E como aqueles eram os únicos brancos que ele estimava passou a odiá-los e com eles a todos os outros. ${ }^{37}$

Apanhou porque não acreditaram em sua raça, em sua cor, $e$ nesta madrugada fugiu. No entanto, como um desejo súbito pelas coisas proibidas, Baldo que nunca tinha pensado em Lindinalva, "daí por diante dormisse com que mulher dormisse, era com Lindinalva que o negro (...) estava dormindo". ${ }^{38}$

A partir deste momento, não terá mais morada. A narrativa ganha novos ritmos a serviço de uma intensa mobilidade, capaz de lançá-lo a todas as aventuras e situações, através das quais sofre as provações, privações e humilhações necessárias para cumprir sua promessa de não ser escravo. Para tanto, a dignidade do herói amadiano é negar a ética do trabalho: a liberdade no não trabalhar $^{39}$, que, no texto, ganha um sentido de resistência em se integrar à ordem e às relações capitalistas. Assim, a cidade é a sua casa $e$ as ruas lhe pertencem. Estes são os privilégios daqueles que se colocam à margem da sociedade amadiana: "a aventura e a liberdade dependem de uma descoberta incessantemente renovada $e$, por conseguinte, do conhecimento $e$ da posse das ruas". ${ }^{40}$

${ }^{37}$ ID., IB., p. 51.

${ }^{38}$ ID., IB., p.52.

${ }^{39}$ Cf. PAlamartchuK, Ana Paula. Ser intelectual comunista... Escritores brasileiros e o comunismo (1920-1945). Dissertação de Mestrado, Campinas, IFCH/Unicamp, 1997.

${ }^{40} \mathrm{SAlAH}$, Jacques. A cidade como personagem. In: FrAGA, M. (org.) Bahia: a cidade de Jorge Amado. Op.cit., p. 95 
Como menino de rua, malandro, lutador de boxe ou artista de circo, o narrador põe em destaque o desapego material de Balduíno, que, movido por essa ética, procura colocar o dinheiro e sua acumulação fora de seus horizontes de ambição: ele não se vende. A tentativa de suborno pelo empresário de um lutador carioca não só fracassa, como também Balduíno engana-o, ficando com o dinheiro:

- Ele quis me comprar, gente... Me deu cem mil-réis para eu perder para aquele raquítico... Eu disse que perdia...Engoli o dinheiro dele e derrubei o homem dele hoje... É pra ele não querer comprar homem... Eu só me vendo por amizade, gente... Agora vamos beber o dinheiro dele... ${ }^{41}$

Ou então, trabalhando em um circo decadente, "dinheiro era coisa que não fazia falta ao negro". ${ }^{42}$ Para Antônio Balduíno, "pouco importava (...) Havia Rosenda. Não pensava noutra coisa" ${ }^{43}$ Tanto neste caso, como no outro, o dinheiro aparece como algo supérfluo na vida do personagem. Como boxeador, o importante era manter sua honra, já como artista circense, havia a mulata Rosenda, o que lhe bastava. Para Eduardo José Tollendal, comportamentos como este de Balduíno encerrariam uma visão romântica de Amado que advogaria "a tese de que um sentimento de pureza quase infantil seria próprio do povo brasileiro" 44 , por conseqüência, do negro. Ora, se observarmos o romance proletário amadiano a idealização romântica e sublime do oprimido, em contraste com a descrição densa e bruta do meio, mostrou-se um recurso privilegiado para que o escritor forjasse um sentido heróico e engrandecedor aos seus personagens. Trata-se

${ }^{41}$ AMADO, J. Jubiabá. Op.cit., p.114 (destaques meus).

${ }^{42}$ ID., IB., p. 194.

${ }^{43}$ ID., IB., p.221.

${ }^{44}$ Tollendal, José Eduardo. Arte Revolucionária, Forma Revolucionária. Tese de Doutorado. Campinas, IEL-Unicamp, 1997, p.61. 
As cores e os gêneros da revolução

menos de um processo essencializador de certas características do povo ou de uma raça, no caso a negra, do que a própria arbitrariedade e deformação da realidade, condição da própria criação literária ${ }^{45}$ que no caso de Jorge Amado dota o proletário, caricatural e romanticamente, com os mais nobres sentimentos humanos. Ou seja, o próprio equacionamento estilístico de Amado à utopia comunista. O ideal como meio de introjetar as esperanças da revolução no mundo presente.

Quando trazemos esta discussão à luz dos modos como o negro e a temática racial foram abordados nessas obras de meados de 1930 do escritor baiano, verificamos que, direta ou indiretamente, alguns trabalhos acabaram por apreendê-las como imagens cristalizadas $e$ isoladas dos problemas mais amplos que seu projeto literário suscitam. Ou seja, por aquilo que a obra do escritor baiano encerraria de estereótipos, preconceitos ou essencializações com relação à raça negra. David Brookshaw, por exemplo, aborda nos romances de Amado algo que ele qualifica de "incongruências" de um escritor branco bem intencionado. Incongruências, pois ao mesmo tempo em que chama a atenção para a cultura africana no Brasil, sua literatura preserva "os mitos brancos concernentes ao afro-brasileiro como indivíduo" 46 , tais como os da figura do negro "sexualmente potente" $e$ "puro instinto" e a da mulata "vaidosa". Ou então, de um modo geral, trabalhos que acionaram as noções raça/classe social ou negro/proletário como etapas rigidamente definidas e estanques em sua produção ${ }^{47}$, perdendo de vista, de um lado, a relação

${ }^{45}$ Cf. CÂNDIDO, Antonio. Literatura e Sociedade. São Paulo, Publifolha, 2000.

${ }^{46}$ Brookshaw, David. Raça \& Cor na Literatura Brasileira. Porto Alegre, Mercado Aberto, 1983, p.133

${ }^{47}$ Tollendal, J. E. Arte Revolucionária... Op. cit; DuARTE, Eduardo de Assis. Jorge Amado: romance em tempo de utopia. Op. cit; RABASSA, Gregory. O Negro na Ficção Brasileira: meio século de história literária. Rio de Janeiro, Tempo Brasileiro, 1965 e PALAmARTCHUK, A. P. Jorge Amado: um escritor de putas e vagabundos? In: ChAlHoub, Sidney \& PeREIRA, Leonardo Affonso de M. (orgs.) 
ambivalente entre estes termos e por outro, as próprias especificidades históricas dos estudos raciais no Brasil.

Não se trata aqui de retomar o desenvolvimento desses estudos no Brasil durante a década de 1930 - e tampouco negar a contribuição valiosa dos trabalhos mencionados - entretanto, é preciso atentarmos para um outro aspecto desta relação entre raça e classe social que diz respeito aos esforços de Amado em promover, conjuntamente com alguns estudiosos da época, a passagem de um sentido puramente biológico e físico do termo "raça" para misturá-lo ${ }^{48} \mathrm{com}$ a noção de cultura. Em Jubiabá, particularmente no capítulo "Macumba", podemos perceber de modo exemplar esses esforços do romancista, sem perder de vista o sabor de novidade que eles conferem à sua literatura.

Os pés descalços das mulheres batiam no chão de barro, dançando. Requebravam o corpo ritualmente, mas esse requebro era sensual e dengoso como corpo quente de negra, como música dengosa de negro. O suor corria e todos estavam tomados pela música e pela dança (...) figuras confusas de mulheres e santos (...) espumando pela boca e pelo sexo (...) No altar católico que estava no canto da sala, Oxóssi era São Jorge; Xangô, São Jerônimo; Omolu, São Roque; e Oxalá, o Senhor do Bonfim - que é o mais milagroso dos santos da cidade negra da Bahia. ${ }^{49}$

A História Contada: capítulos de história social da literatura, Rio de Janeiro, Nova Fronteira, 1997.

${ }^{48}$ A explicação sobre a realidade racial brasileira naquele momento, "apesar de misturá-la com a noção de cultura, ainda reificava a noção de raça como parte do substrato orgânico e/ou psicológico do indivíduo". Cf. CoRRÊA, M. As Ilusóes da Liberdade. Bragança Paulista, Ed. USF, 2001, p.240. Cf, também da autora, Antropólogas e Antropologia. Op. cit. Ainda, sobre o modo como as noções de raça e cultura foram articuladas na obra de Gilberto Freyre, cf, ARAÚJO, Ricardo Benzaquem de. Guerra e Paz: Casa-Grande e Senzala e a obra de Gilberto Freyre nos anos 30. Rio de Janeiro, Ed.34, 1994.

${ }^{49}$ AMADO, J. Jubiabá. Op. cit., pp.93-94 (destaques meus). 
As cores e os gêneros da revolução

Seria preciso reproduzir o capítulo inteiro para que pudéssemos apreender tanto a riqueza de detalhes com que o cenário é construído, quanto as variadas velocidades com que a narrativa é conduzida, a fim de dar conta das várias "etapas" do ritual. A macumba do pai-de-santo Jubiabá é revelada a partir de seus aspectos envolventes, a medida que integra todos aqueles que se encontram no terreiro: "- Eu caio já na dança..." 50 , diz o homem branco para um estudante negro. Este estava completamente envolvido "pela música e pelos cânticos, esquecido de que tinha vindo observar". ${ }^{51}$ A narrativa assume uma cadência fortemente sugestiva da "música monótona" que domina o lugar: o canto da mãe do terreiro e a resposta em coro da assistência que "animava o santo"; os movimentos dos corpos das pessoas, as pancadas de mãos nos joelhos e os pés batendo no chão. Tudo parece arranjado para criar um efeito de sons de batuques que, se não podemos ouvir, podemos sentir pulsando no texto.

$\mathrm{O}$ narrador parece não estar alheio à cena. $\mathrm{O}$ tratamento que dá ao ritual deixa depreender seu envolvimento e, também, o conhecimento de tudo que está acontecendo. Nada o surpreende. Inclusive a situação, bastante inverossímil, de mulheres espumando "pela boca e pelo sexo", no momento em que são possuídas pelos santos, não abala a naturalidade com que trata as pessoas e o ritual da macumba. Ao mesmo tempo, seu olhar não gera ambigüidades ou dúvidas quanto ao que se é visto. $\mathrm{O}$ material e o imaterial são vistos e concebidos como uma realidade única: mulheres que naquele momento são os próprios santos.

O negro, em Jubiabá, emerge enquanto um sujeito portador de uma cultura própria e particular, entretanto, sem romper em definitivo com o sentido orgânico que a chave racial oferecia: os corpos das mulheres requebravam "ritualmente", sem com isto, deixar de requebrar de maneira "sensual" e "dengosa" como

${ }^{50}$ ID., IB., p.93. 
"corpo quente de negra". Ou seja, em apenas um parágrafo, Jorge Amado consegue sintetizar estas duas dimensões, biológica e cultural, que o negro - a negra, vale destacar ${ }^{52}$ - encerraria na sua constituição enquanto grupo $e$ indivíduo. O corpo não só é apreendido pela sua economia dos gestos, movimentos e técnicas sociais e culturalmente condicionados, como também é apropriado por características intrínsecas a sua natureza física. Ainda, é importante chamar atenção para o altar católico que o narrador aponta no canto da sala, no qual se encontra o santo mais milagroso da "cidade negra da Bahia". E aqui, podemos perguntar: qual o sentido do ser negro para Jorge Amado neste momento? Pois, a passagem em questão deixa entrever que não se trata meramente de uma cor física. A cidade, ao menos parte dela, não é negra devido à composição fenotípica de sua população, mas sim em função de sua realidade cultural sincrética $e$ "espiritualmente" mestiça. ${ }^{53}$ Trata-se de uma cor, como bem observou Lourdes Martínez-Echazábal,

\footnotetext{
${ }^{52} \mathrm{O}$ caso de ser uma "negra" e não um "negro" torna-se interessante para percebermos como Jorge Amado parece efetuar uma associação bastante cara ao pensamento antropológico brasileiro, na qual teria sido recorrente a homologia entre "negro" e "mulher", particularmente, quando se falava sobre as "possessões", como é o caso da passagem no romance. Como observou Mariza Corrêa em seu trabalho sobre Nina Rodrigues, o sexo feminino e a raça negra seriam tratados por Nina Rodrigues como um coisa só: "Aparentemente interessado no segundo, é do primeiro que ele estava falando (...) a ponto de confundir o gênero dos sujeitos de suas frases quando descrevia uma sessão de candomblé". CORRÊA, M. As Ilusóes da Liberdade. Op. cit., p.119.

${ }^{53}$ Não precisamos ir muito longe para enxergarmos as afinidades de Jorge Amado com os estudos raciais na década de 1930 e com o fato das influências negro africanas estarem marcadas na "alma" do brasileiro e não só no corpo. Vale lembrar a clássica passagem de Gilberto Freyre, quando diz: "Todo brasileiro, mesmo o alvo de cabelo loiro, traz na alma quando não no corpo (...) a sombra, ou pelo menos a pinta, do indígena ou do negro (...) principalmente do negro". Freyre, G. Casa-Grande \& Senzala. Rio de Janeiro, Record, 2000, p.343.
} 
As cores e os gêneros da revolução

espiritual, corporificada nos conceitos de cultura afrobrasileira e classe social (...) uma vez que o ser negro ou branco ou mulato afirma-se não através da cor da pele, $e$ sim mediante diversas formas social e culturalmente determinadas de apreender o mundo. ${ }^{54}$

Dito isto, Jubiabá mostra-se um romance bastante representativo do alinhamento do autor ao tom predominante dos estudos raciais naquele momento. Jorge Amado encontra na cultura afro-brasileira uma beleza e um tema digno de ficcionalização, ao mesmo tempo em que, e principalmente, a reveste de um sentido heróico, baseado naquilo que ela encerra de um grupo sofrido, historicamente escravizado e colocado à margem da sociedade. Os negros e seus descendentes apresentam-se aos olhos de Amado como os oprimidos por excelência, pois ainda não conseguiram realizar sua "verdadeira" abolição, excluídos duplamente: como raça e como classe. ${ }^{55}$ Não por acaso, morro e cidade constituem espaços bem definidos em Jubiabá, marcando nitidamente os lugares. Se, em um primeiro momento, o morro forneceu as chaves para que Balduíno compreendesse a sua opressão enquanto negro, em um segundo, seu deslocamento para a cidade permitiu-lhe perceber os grilhões mais amplos que o escravizam.

\footnotetext{
${ }^{54}$ MARTINEZ-ECHAZÁBAL, Lourdes. O culturalismo dos anos 30 no Brasil e na América Latina: deslocamento retórico ou conceitual? In: MAIO, Marcos Chao \& SANTOS, Ricardo Ventura. (orgs.) Raça, Ciência e Sociedade. Rio de Janeiro, FIOCRUZ/CCBB, 1996, p.118.

${ }^{55}$ Mais uma vez, esta perspectiva do escritor baiano mostra-se bastante afinada à de seu colega e conterrâneo Édison Carneiro, ao afirmar que no contexto capitalista, "o negro se proletarizou (...) forçado a descer, ainda mais do que com a escravidão, sob essa outra escravidão que era o capitalismo (...) os negros conscientes (...) sabem perfeitamente que os seus interesses imediatos e futuros não são em nada diversos dos do proletariado em geral" Cf. CARNEIRO, Édison. A situação do negro no Brasil. In: FREYRE, G. et alii. Estudos Afro-brasileiros, vol. 1, Recife, Massangana, 1988 [1934], pp.237 e 240. Cf, também, CARNEIRO, Édison. Religióes Negras/Negros Bantos. Rio de Janeiro, Civilização Brasileira, 1991.
} 
O forte veio folhetinesco de Jubiabá, com um enredo de alta carga emocional, parece se desvelar inteiramente quando observamos as soluções internas que Jorge Amado dá para lançar o protagonista no espaço que ele evitou a vida inteira: aquele das fábricas e dos ofícios proletários. É a partir do reaparecimento de Lindinalva, que o romance encaminha a transformação do Balduíno livre e inconseqüente, para sua efetiva "proletarização" e descoberta da militância política responsável. Subitamente empobrecida, prostituída e a beira da morte, Lindinalva reencontra Baldo a quem lhe pediu que cuidasse de seu filho. São estas razões de ordem sentimental que permitem Balduíno completar seu aprendizado ao assumir dois novos papéis, o de pai e de trabalhador regular: "Para ajudar o filho de Lindinalva, o negro Antônio Balduíno entrou para a estiva (...) Ia ter uma profissão, ia ser escravo". ${ }^{56}$

No entanto, não há qualquer aprofundamento desses novos papéis do personagem. Suas relações como pai e trabalhador servem apenas como pano de fundo para que Balduíno conheça a greve. Ou seja, Baldo somente é lançado no espaço da escravidão na justa medida em que o cenário $e$ as condições estejam formados para que possa ser um homem livre. A greve era uma coisa nova para o herói,

nunca tinha pensado nisso (...) Mas era bom (...) sempre tivera um grande desprezo pelos que trabalhavam (...) mas agora o negro olhava com um outro respeito os trabalhadores. Eles podiam deixar de ser escravos (...) foi como se nascesse de novo. ${ }^{57}$

A "proletarização" de Balduíno, seu contato com o sindicato dos estivadores do porto e com a militância na greve, impõe-lhe profundas reavaliações de seu passado, de sua identidade e suas

${ }^{56}$ AMADO, J. Jubiabá. Op.cit., p.274.

${ }^{57}$ ID., IB., pp.280-81. 
As cores e os gêneros da revolução

tomadas de posição no mundo social. Entretanto, é interessante percebermos que o "renascimento" de Balduíno não gera uma descontinuidade ou ruptura com seu passado, mas sim um processo de incorporação e alargamento de sua compreensão do mundo.

A cidade é envolvida pelos sons de batuque que vêm da macumba de Jubiabá. Hoje esses sons de batuque soam aos ouvidos do negro Antônio Balduíno como sons guerreiros, como sons de libertação. A estrela que é Zumbi dos Palmares no céu claro. Um estudante certa vez se riu do negro (...) e disse que aquela estrela não era estrela, era o planeta Vênus. Mas ele ri do estudante (...) Aquele dia de greve fora dos mais bonitos da sua vida (...) Ele agora sabe por que luta. E vai assim correndo avisar todos os negros que estão na macumba (...) - Meu povo, vocês não sabem nada (...) Vocês precisam ver a greve (...) Negro faz greve, não é mais escravo. Que adianta negro rezar (...) Os ricos manda fechar a festa de Oxóssi. Uma vez os polícias fecharam a festa (...) E pai Jubiabá foi com eles, foi pra cadeia (...) Negro não pode fazer nada, nem dançar para santo (...) Negro pode tudo, negro pode fazer o que quiser (...) Negro e branco pobre, tudo é escravo, mas tem tudo na mão. É só não querer, não é mais escravo. Meu povo, vamos pra greve. ${ }^{58}$

A passagem é significativa dos equacionamentos que Jorge Amado efetuou para conceber a questão racial, alinhada às perspectivas de seu projeto político em uma chave marxista. Participando da greve e tomando contato com uma organização política, Balduíno encontra, enfim, seu lugar no mundo, junto a sua classe, em uma luta consciente. Uma luta pela "verdadeira" liberdade, não apenas de sua raça, mas de todo o proletariado. Entretanto, acredito que a narrativa é conduzida de modo a não haver um sentido de ruptura ou incompatibilidade entre essas

${ }^{58}$ ID., IB., pp.286-87. 
duas lutas, ou dois momentos na vida de Balduíno: o negro-raça e o negro-classe, se assim posso dizer. Há, sim, uma forte idéia de ambivalência dessas duas dimensões, na qual a cultura afrobrasileira é acionada como elemento catalisador da consciência "revolucionária" do protagonista.

Deste modo, a militância, menos que "desfazer" - ou entrar em contradição - parece reafirmar ainda mais a presença do universo mítico e lendário em Jubiabá: os batuques da macumba deixam de ter apenas uma função e um significado "religiosos", para serem complementados por aqueles político e libertário, impulsionando a cidade para a luta, ao mesmo tempo em que, Zumbi, sob a forma de uma estrela, ilumina o caminho de Balduíno. De modo que a incorporação do negro ao proletariado, para Jorge Amado, não implica na supressão de suas particularidades culturais. O que ocorre, em verdade, é uma hierarquia de valores, na qual a consciência formulada unicamente em termos raciais mostra-se insuficiente como horizonte de ação política. Ela deve ser encompassada por uma identidade considerada mais ampla: a de classe. Embora conceba o personagem principal como um representante de uma cultura específica, ele participa "da sociedade nacional, antes como 'proletário' do que como 'negro'. Uma posição recobre a outra sem, no entanto, suprimi-la". 59

A integração de Balduíno em uma sociedade de classes e o seu posterior engajamento na militância comunista não rompe, em absoluto, com as concepções de mundo que havia aprendido na sua infância no morro. A realidade continua a ser interpretada pelo herói como aqueles que possuem o "olho da piedade" $e$ outros o "olho da ruindade". Porém, se antes esta classificação era usada para dividir o mundo entre brancos e negros, agora, ela foi resignificada para acomodar ricos e pobres: "descobriu o que os $\mathrm{ABC}$ ensinavam (...) Os ricos tinham secado o olho da piedade. Mas eles podem, na hora que quiserem, secar o olho da

${ }^{59}$ AlmeidA, A. W. B. de. Jorge Amado: politica e literatura... Op. cit., pp.121-22. 
As cores e os gêneros da revolução

ruindade" ${ }^{60}$ Assim, interpretar ou identificar-se com o mundo racialmente, para Jorge Amado, não implica em uma postura contraditória ou oposta ao sentimento de pertencer a uma classe e agir enquanto tal. O romancista baiano parece estar atento aos problemas particulares que a projeção da utopia comunista engendra na sociedade brasileira, na qual, dada a sua formação histórica, falar em classe social é necessariamente passar pelos problemas de ordem racial.

Deste modo, a partir de Jubiabá, Amado almeja um projeto político-literário, no qual compreender o negro brasileiro é, principalmente, mergulhar em uma forma cultural e socialmente construída de perceber o mundo, um universo mítico e lendário afro-brasileiro. Um universo que, do ponto de vista da realidade baiana, forma aos olhos do escritor o "elemento popular" por excelência. O problema racial encerra, aos olhos de Amado, um tema privilegiado para se pensar - mas, sobretudo, idealizar - a tão almejada revolução comunista, tendo-se em vista a miscigenação biológica e cultural que conformaria o povo brasileiro.

Em agosto de 1936, a publicação de Mar Morto, de um certo modo, vem sedimentar este "mergulho" de Jorge Amado na vida popular-proletária desvelada a partir da existência dos "homens do mar", dos pescadores e marinheiros filhos de Iemanjá. Trata-se da história de Guma, condutor de saveiros na cidade de Salvador, e sua impossibilidade de fugir aos desígnios de uma realidade vista pelo espectro mítico que a ordena: atender ao chamados de Iemanjá e ir morrer no fundo das águas do mar. Porém, neste seu quinto romance, Jorge Amado lança mão de uma literatura "suavizada", amena e mais contida no que diz respeito ao teor político. A aspereza narrativa cede lugar a um tratamento lírico $e$ sentimental deste tipo humano que são "os homens da beira do cais". Homens, mas também suas mulheres, que parecem se relacionar por uma lógica específica com o mundo, onde o tempo

${ }^{60}$ AMADO, J. Jubiabá. Op. cit., p.316. 
e o espaço não existem apartados do significado mítico que os engendram: a vida surge como uma espécie de dádiva que Iemanjá lhes concede e o mar, sua morada.

Quando se tem em vista a violência e a brutalidade que marcaram o universo amadiano até então, Mar Morto chega a causar um certo estranhamento no leitor pela abordagem lírica $e$ dramática que a narrativa oferece da relação amorosa entre os personagens Guma e Lívia. Uma história que, como Amado explica na apresentação do romance, "se não vos parecer bela (...) é que a ouvistes da boca de um homem da terra e, dificilmente, um homem da terra entende o coração dos marinheiros" ${ }^{61}$ Neste sentido, diferente de Jubiabá, por exemplo, onde o narrador procurava se colocar em um certo grau de distanciamento para que o morro e a cidade pudessem ser apreendidos - sendo a cidade o destino social e político do personagem - em Mar Morto podemos perceber um maior "envolvimento", a partir do qual tudo que se encontra para além deste universo particular, que são os homens do mar e a vida na beira do cais, surge como espaço estranho, hostil, e, deste modo, sem importância para a construção do enredo. Inclusive a cidade:

Na cidade era tudo claro e sem mistério como a luz das lâmpadas. No mar tudo era misterioso como a luz das estrelas. As estradas da cidade eram muitas e bem calçadas. No mar só havia uma estrada e essa oscilava, era perigosa. As estradas da cidade já estavam há muito conquistadas. A do mar era conquistada diariamente, era ir a uma aventura toda vez que se partia. E na terra não há Iemanjá, não há festas de dona Janaína (...) Guma nunca foi tentado pela terra. $^{62}$

Assim, os limites humanos que engendram a construção de Mar Morto encontram-se fundamentados pela dimensão do mito

${ }^{61}$ ID., Mar Morto. $60^{a}$ ed., Rio de Janeiro, Record, 1986, p.9.

62 ID., IB., p.46 (destaques meus). 
As cores e os gêneros da revolução

$e$, neste sentido, o narrador procura se ater apenas àqueles que o vivenciam. Falar de pessoas ou lugares onde "não há Iemanjá" implica colocar-se fora desta dimensão. Ou ainda, se prestarmos atenção em um outro nível de profundidade, em Mar Morto, as motivações que estão na base das ações e da tessitura existencial de Guma são concebidas à luz da própria explicação mítica sobre o nascimento dos orixás. Acredito ser interessante reproduzir, aqui, este entrecho mítico para deixar mais nítida minha argumentação:

da união de Obatalá, o céu, mais Odúdúa, nasceram Aganjú, a terra firme, e Yêmanjá, as águas. E, da união destes dois, nasceu Orungán, o ar, tudo que existe entre a terra e o céu - o qual se apaixonou seriamente por Yêmanjá, sua mãe, até conseguir violá-la. Fugindo às propostas canalhas do filho (...) perseguida por ele, morreu - e, dos seios, tornados enormes, nasceram dois rios, que se reuniram adeante, formando uma lagoa, ao passo que, do ventre rompido, surgiram todos os orixás que povoam a imaginação do negro. ${ }^{63}$

Este dado etnográfico, bastante difundido nos trabalhos de Édison Carneiro e Arthur Ramos por exemplo, é a matéria-prima fundamental do romance. Embora o narrador, em uma certa altura da história, informe ao leitor as semelhanças entre Guma e Orungã (o filho de Iemanjá), esta motivação pode ser sentida também na maneira como o enredo é arranjado.

Tendo perdido o pai na infância, que afogou-se em um dia de tempestade, Guma fora criado pelo tio. Da mãe, o personagem não havia guardado qualquer lembrança. Logo que nasceu, a mulher levou o menino para o pai e nunca mais voltou. Estas são

${ }^{63}$ CARneiro, E. A rainha do mar. Boletim de Ariel, no 7 , abril de 1936, p.178. Esta mítica da criação dos orixás encontra-se mecionada, também, nos trabalhos de CARNeIRO, E. Religióes Negras... Op.cit., em especial, pp.44-45 e RAMOS, Arthur. Folk-lore Negro no Brasil. Rio de Janeiro, Civilização Brasileira, 1935, pp.16-17. 
as condições, fundamentais, para que o narrador consiga criar um cenário, no qual possa tirar partido de toda a dramaticidade que o entrecho mítico suscita. Alheio a qualquer sentimento materno, Guma, já adolescente com seus onze anos, ao reencontrar sua mãe é tomado por toda espécie de desejos e fantasias na medida em acreditava ser uma prostituta trazida pelo tio. Ao ouvir a voz na sala, "Guma sabia que se tratava de dormir com uma mulher (...) seu tio trazia a mulher prometida" ${ }^{64} \mathrm{~A}$ hora em que a vê, um "desejo violento" o invade, mas neste exato momento o tio lhe avisa:

- É tua mãe, Guma.

E o desejo não fugiu. Não era possível que fosse sua mãe, aquela mãe em quem nunca lhe falara, mãe em quem nunca pensara. Uma pilhéria de seu tio com certeza. Aquela que estava ali era uma mulher da rua que viera para dormir com ele (...) Mas a mulher se aproxima dele e o beija como devem beijar as mães (...) Então Guma começa a chorar e ele mesmo não sabe se é por ter encontrado sua mãe, se é por ter perdido a mulher que esperava (...) E pela primeira vez pensou em ir ao encontro de lemanjá (...) que é ao mesmo tempo mãe e mulher de todos que vivem no mar. ${ }^{65}$

A surpresa de Guma é proporcional a sua frustração em descobrir naquela mulher, sua mãe. A ambigüidade de sentimentos despertados no personagem, o materno e o sexual, $e$ a impossibilidade de concretizá-los de uma só vez selam definitivamente o seu destino que, a partir de então, "estaria regido por normas equivalentes ao destino de Orungã, que amara Janaína, e ao seu seio voltaria, ao seio da esposa-mãe. ${ }^{66}$ Ou seja, o destino de Guma é morrer para que ambos os sentimentos sejam plenamente satisfeitos, pois só Iemanjá pode ser "mãe e

${ }^{64}$ AMADO, J. Mar Morto. Op.cit., p.32.

${ }^{65}$ ID., IB., pp.34-35.

${ }^{66}$ TÁTI, Miécio. Jorge Amado: vida e obra. Belo Horizonte, Itatiaia, 1961, p.86. 
As cores e os gêneros da revolução

mulher" ao mesmo tempo. De um certo modo, poderíamos dizer que Mar Morto é estilisticamente concebido pelo constante retardamento desta morte anunciada. Uma narrativa em que toda ação deixa em suspenso o momento derradeiro, no qual o filho dileto de Iemanjá partirá para junto dela nas "terras do sem fim".

Assim, ao olhar para este romance (mas também, Jubiabá e Capitães da Areia), meu interesse é prestar atenção às clivagens políticas, de corte marxista, que o romancista baiano efetuou no tratamento de seu "material" afro-brasileiro. Clivagem esta que, em Mar Morto, procurou assentar alegoricamente no processo de renovação e transformação do mito de Iemanjá, encenado pela trajetória do personagem Guma, uma idéia de subversão e de possibilidade de mudanças na ordem social. Pois, vale lembrar, Guma

era como Orungã, era um sofrimento que se repetia. Por isso, talvez lemanjá o amasse e protegesse (...) Por isso, para que ele não ficasse como Orungã, ela devia dar-lhe uma mulher bonita, quase tão bonita como Dona Janaína mesma. ${ }^{67}$

Esta mulher seria Lívia, quem o personagem conheceu justamente em noite de festa a Iemanjá no terreiro. A relação amorosa entre Guma e Lívia, a mulher que o orixá lhe enviou, transforma-se no sopro criativo para que Amado criasse um enredo sob a constante tensão entre as vontades humanas e os desígnios da ordem mítica. O personagem quer fugir, pois o enlace significa selar o destino de Lívia. O destino de toda mulher de pescador, "a ficar sem seu homem (...) sem comida, a serem logo engolidas ou por uma fábrica ou pela prostituição (...) Guma se horroriza só de pensar em Lívia". ${ }^{68}$ Entretanto, estas inquietações e receios que permeiam os pensamentos de Guma,

${ }^{67}$ AMADO, J. Mar Morto. Op. cit., p.71.

${ }^{68}$ ID., IB., p. 104. 
menos que gerarem um efeito de dúvida ou incerteza quanto ao desfecho do casal, parecem servir como um recurso valioso para que o texto venha reafirmar cada vez mais o fim trágico, mas inevitável, do herói: "ele não pode discutir as ordens de lemanjá (...) Guma não quer desgraçar o destino de Lívia, mas não pode". ${ }^{69}$

O personagem projeta um futuro impossível de se concretizar, enquanto o tempo presente ao plano narrativo encerra dilemas, cujas soluções já estão previamente dadas. Todo o universo do romance encontra-se organizado por esta tensão de forças entre a disposição e a incapacidade do personagem em fugir aos desígnios divinos. Assim, à luz desta "estrutura permanente"70 com que o enredo é "costurado", Jorge Amado revela sua implícita intencionalidade de provocar o acirramento dessa tensão, desse fatalismo, preparando o cenário para uma transformação inesperada.

Realizado o casamento e gerado um filho de Guma, Lívia "teme cada vez mais (...) tamanha é a certeza que ela tem que toda vez que o vê [Guma] voltar é como se o visse ressuscitar". ${ }^{71}$ $\mathrm{O}$ personagem tem seu barco destruído em um acidente, entretanto, entre "alugar seu braço" ou "viver lá em cima"72 (na cidade), prefere se endividar com um outro saveiro e, para pagálo, passa a carregar tecidos contrabandeados. As adversidades e obstáculos que se colocam em seu caminho mostram-se absolutamente necessários para que cada vez mais adie sua promessa de ir para a cidade. Promessa feita à Lívia, que via nesta mudança a possibilidade de ambos fugirem dos tentáculos de

${ }^{69}$ ID., IB., p. 110.

70 "Um mito diz respeito, sempre, a acontecimentos passados [que] formam também uma estrutura permanente. Esta se relaciona simultaneamente ao passado, presente e futuro". Cf. LÉVI-STRAUSS, Claude. A estrutura dos mitos. In: Antropologia Estrutural. Rio de Janeiro, Tempo Brasileiro, 1970, p.229 (destaques meus).

${ }^{71}$ AMADO, J. Mar Morto. Op.cit., p.173.

72 ID., IB., p. 181. 
As cores e os gêneros da revolução

Iemanjá. Entretanto, tudo parece conduzir e anunciar o cumprimento da lei inexorável do cais.

Quando finalmente Guma morre, como se o orixá o estivesse punindo por ousar abandonar a vida da beira do cais, todos pensam que Lívia irá embora para a cidade. Afinal, ela era "da terra" e não compreendia as leis daquele lugar. O mar "não era a sua estrada. Ela a tomou por amor" ${ }^{73}$ Mas, justamente, por vir de "outro destino", "não aceita essa lei como uma fatalidade (...) Ela lutou, ela ia vencer. Ia vencer...". ${ }^{74}$ Poderíamos perguntar, vencer o que? E, como? A luta de Lívia para mudar o destino de Guma perderia todo o sentido, caso retornasse à cidade. Ir embora da beira do cais significaria levar adiante o percurso igual de todas as mulheres que perdem seus maridos: serem engolidas pelas fábricas ou tornarem-se prostitutas. Sua vitória deve se concretizar através de um gesto que subverta a lógica do cais e, deste modo, a própria ordem mítica.

Aquela decisão de Lívia de não se prostituir, de se entregar ao trabalho no mar, faz parte (...) do milagre que Dona Dulce espera. Ele está se realizando (...) Para se sentir novamente com Guma terá que vir ao mar (...) Rosa Palmeirão botou a navalha na saia, o punhal no peito (...) Parece um homem em cima do "Paquete Voador". Mas Lívia é bem mulher, frágil mulher (...) Rosa Palmeirão vai no leme (...) Olharam e viram. Dona Dulce olhou também da janela da escola. Viu uma mulher forte que lutava. A luta era seu milagre. Começava a se realizar. No cais os marítimos viam Iemanjá, a dos cinco nomes. O velho Francisco gritava, era a segunda vez que ele a via. Assim contam na beira do cais". ${ }^{75}$

\footnotetext{
${ }^{73}$ ID., IB., p.215.

${ }^{74}$ ID., IB.

${ }^{75}$ ID., IB., pp.219-222.
} 
Como lembra Ana Paula Palamartchuk, o sentido de ruptura e transformação construído em Mar Morto encontra-se internamente ancorado no deslocamento de Lívia para "os lugares considerados tipicamente masculinos". ${ }^{76}$ No entanto, mais que isto, podemos perceber no gesto da personagem a possibilidade de recolocar a vida nos limites das vontades humanas. Jorge Amado parece, então, implicitamente dar cabo aos ventos políticos que sacodem sua produção romanesca, quando Lívia aponta para a existência de uma outra opção naquele universo social. Como se o fato de não vender o corpo (prostituição) e sua força de trabalho permitisse-lhe ocupar um espaço alternativo àqueles degradantes e desumanizadores que o capitalismo oferecem. Esta postura dos personagens amadianos em negar as "ocupações proletárias", constitui por si só um ato revestido de enorme grandeza e heroicidade. Se lembrarmos de Balduíno, a mola propulsora de seus deslocamentos como menino de rua, malandro ou boxeador encontra-se alimentada pela sua promessa em não ser escravo $e$, neste sentido, não se submeter às explorações da fábrica. Isto porque o sentido de dignidade $e$ heroicidade que Jorge Amado quer construir em seus personagens é inerente à posição que eles ocupam e querem ocupar na sociedade. Ou seja, "fora" das relações, valores e espaços através dos quais o capitalismo e suas classes dominantes se reproduzem.

Este é o "milagre" que a professora Dona Dulce, em Mar Morto, esperava. Ele, enfim, começou a se concretizar. O mito não mais subordinando, mas sobretudo impulsionando as pessoas da beira do cais para um outro caminho, pois a morte não é mais o preço que se paga, no caso dos homens, para quem vê Iemanjá. Pelo contrário, agora, ela aparece encarnada naquela mulher que teve a coragem de "domar" os seus caprichos de "mãe e esposa", mostrando-se para os marítimos como símbolo da vida. Ao mesmo tempo, para as mulheres, Lívia assinala a ampliação de um campo de possibilidades. Aliás, bem ao gosto do romancista, a

${ }^{76}$ PalamartchuK, A. P. Ser intelectual comunista... Op. cit., p.135. 
As cores e os gêneros da revolução

única possibilidade "digna" de existir em uma sociedade de tipo capitalista. Assim, é no cruzamento de dois movimentos conjuntos que Lívia consegue inverter a lógica local: um primeiro, no qual a personagem rompe com as "determinações" de gênero da ordem social e, um segundo, em que ela corporifica a "divindade negra", Iemanjá. Orixá expressivo da cultura afro-brasileira, convertido no romance em símbolo de "vida", "força" e "luta". A morte de Guma torna-se, então, a contrapartida absolutamente necessária para que possa haver o renascimento de uma nova forma de interpretar, vivenciar e se relacionar com a ordem mítica e, por conseqüência, social.

Dito de outra forma, ao mobilizar noções e classificações de cunho racial na construção de Mar Morto, Jorge Amado parece ter encontrado implicitamente na figura feminina uma referência interessante para trabalhar com duas categorias socialmente excluídas: a de negro e mulher, a exemplo do binômio negro/proletário com o qual Balduíno foi "revestido" em Jubiabá. Lívia apresenta-se como uma personagem que encenaria alusivamente uma dupla subordinação na sociedade:

a hierarquia sexual não estava em discussão mas parece servir como referência à essa nova classificação [a racial], também hierárquica, a ser aplicada às diferenças naturais (...) como se fosse impossível tratar de raça sem tratar de sexo ou sexualidade". ${ }^{77}$

Assim, minha insistência em mostrar como Mar Morto tem sua contextura narrativa concebida a partir de um entrecho mítico específico, encerra uma preocupação em esquadrinhar o aproveitamento que Jorge Amado efetuou da cultura afrobrasileira, sem restringi-lo à constatação simplista da presença de negros, assim como de suas imagens e/ou estereótipos, principalmente neste dois últimos romances (Jubiabá e Mar

${ }^{77}$ CorrêA, Mariza. A invenção da mulata. Cadernos Pagu (6/7) - raça e gêneroNúcleo de Estudos de Gênero - Pagu/Unicamp, 1996, p.43. 
Morto). Poderia ter destacado no decorrer de minha análise passagens em que o escritor se debruçou - quase que sistematicamente - sobre rituais religiosos, os terreiros, a posse dos santos, os cânticos do candomblé, enfim, cenas e cenários de grande riqueza, não só estética, mas também etnográfica. ${ }^{78}$ Entretanto, a opção em acompanhar mais detidamente a condução do romance fornece uma outra forma de entrada, mais interessante, de perceber e apreender o diálogo de Jorge Amado com a chamada questão racial naqueles anos de 1930. Pois, para mostrá-lo não precisei, necessariamente, mencionar "a cor" dos personagens.

Ao mesmo tempo, pareceu-me um modo de abordagem mais apropriado para captarmos como Jorge Amado lança seu ideário comunista em Mar Morto. A linguagem suavizada e "revestida" de intenso lirismo conforma um texto onde a mensagem política, assim como a "objetividade" do escritor, surgem deformadas pela intenção narrativa de contar algo despreocupado de seu efetivo valor "real". Como se as próprias histórias que "assim [se] contam na beira do cais"79 fossem capazes de levar uma mensagem de esperança e, sobretudo, de possibilidades de mudanças. Estas, mais uma vez, abordadas por Jorge Amado na sua relação com a cultura afro-brasileira, entendida como o elemento catalisador das consciências revolucionárias em seu universo romanesco.

\footnotetext{
${ }^{78}$ Um pequeno exemplo desses momentos pode ser depreendido da festa para Iemanjá: "Faz meses que estas negras, que hoje são feitas, foram iniciadas. Primeiro deram a todas elas um banho com as folhas sagradas, rasparam-lhe os cabelos da cabeça, das axilas e do púbis, para que o santo mais livremente possa penetrar (...) Tiveram as cabeças pintadas e também as faces com cores berrantes. Receberam então Iemanjá que penetrou nelas ou pela cabeça ou pelas axilas (...) elas ficaram todos esses meses recolhidas. Não conheceram homem, não viram movimento da rua e do mar. Viveram só para Iemanjá. Hoje é o dia da grande festa quando elas ficarão mesmo feitas, mesmo sacerdotisas de Iemanjá". Cf. AMADO, Jorge. Mar Morto. Op. cit., p.74.

${ }^{79}$ AMADO, J. Mar Morto. Op.cit., p.223.
} 
As cores e os gêneros da revolução

Jorge Amado parece trabalhar com uma idéia de que não se é negro, mas se está negro. A identificação e o sentimento de pertencer ou não a uma raça se definindo mediante posições específicas ocupadas pelos sujeitos na estrutura social e no campo das lutas políticas: "a greve é dos condutores de bondes, dos operários das oficinas e força e luz (...) Tem até muito espanhol entre eles, muito branco (...) Mas todo pobre já virou negro". 80 Esta passagem que, em Jubiabá, marca a descoberta da militância e o engajamento de Balduíno na greve, revela de modo exemplar o duplo movimento, proletarizador e racializador, que o romancista desenvolve na sua mimesis literária e a partir do qual o repertório cultural do personagem é acionado como o "filtro" interpretativo de suas experiências.

Em Capitães da Areia, através da saga de Pedro Bala e seu grupo de meninos de rua, esse modo como Jorge Amado trabalhou a questão racial, articulado às posições que seus personagens ocupam no universo social e cultural, parece ganhar contornos ainda mais nítidos na medida em que coloca como protagonista um menino fenotipicamente branco. A trajetória de Pedro Bala e a sua luta diária para sobreviver nas ruas de Salvador engendram um processo de aprendizagem no qual seu contato com o "povo do candomblé" mostra-se fundamental para que consiga descobrir um sentido para a luta e militância, implicando em um movimento "enegrecedor" do personagem no âmbito social.

Ao trazer um grupo de crianças abandonadas para o centro de seu romance, Jorge Amado quer extrair destas vidas as experiências diárias que empreendem para sobreviver em um ambiente de pobreza e violência, cada uma delas carregadas de pequenas tragédias sociais e familiares:

crianças abandonadas que viviam do furto. Nunca ninguém soube o número exato de meninos que assim viviam. Eram

${ }^{80}$ ID., Jubiabá. Op. cit., p.278. 
bem uns cem (...) Vestidos de farrapos, sujos, semiesfomeados, agressivos, soltando palavrões e fumando (...) eram, em verdade, os donos da cidade, os que a conheciam totalmente, os que totalmente a amavam. ${ }^{81}$

Entretanto, em meio a todas estas crianças, uma em particular parece chamar a atenção do narrador: Pedro Bala, que "trazia nos olhos e na voz a autoridade do chefe" ${ }^{82}$ Liderando as ações e os trabalhos, conseguiu o respeito unânime do grupo e graças a sua inteligência e ousadia "a cidade começou a ouvir falar nos Capitães da Areia". ${ }^{83}$ Entretanto,

Nada possuíam além da liberdade de correr as ruas. Levavam vida nem sempre fácil, arranjando o que comer e o que vestir, ora carregando uma mala, ora furtando carteiras e chapéus (...) Nenhuma delas [as crianças] reclamava. Por vezes morria um de moléstia (...) Quando calhava vir o padre José Pedro, ou mãe-de-santo Don'Aninha (...) o doente tinha alguma salvação (...) E achava que a alegria daquela liberdade era pouca para a desgraça daquela vida. ${ }^{84}$

Neste seu sexto romance, Jorge Amado parece retomar recursos narrativos já explorados em Jubiabá: o modelo de construção do herói que, vivendo nas ruas toda espécie de adversidade e humilhação, encontra nas lutas sociais e na greve o caminho para a revolta coerente e responsável, bem como um enredo onde cenários e situações encontram-se preparados para que o protagonista possa mostrar constantemente suas aspirações e ações, sempre motivadas por sentimentos nobres. Em verdade, fica-se até com a impressão que Capitães da Areia constitui a

${ }^{81}$ ID., Capitães da Areia. $71^{\text {a }}$ ed., Rio de Janeiro, Record, 1991, p.27.

${ }^{82}$ ID., IB., p.26.

${ }^{83}$ ID., IB., p. 27.

${ }^{84}$ ID., IB., p. 42. 
As cores e os gêneros da revolução

infância de Balduíno nas ruas, só que agora vista com uma lente de aumento.

Desta forma, nas ruas, Pedro Bala vai tomando conhecimento de quem "realmente" é. Nelas descobre quem foi o seu pai, "só agora o sabia. E por eles [os estivadores] fizera discursos trepado em caixão, brigara, recebera uma bala (...) também poderia fazer greve assim como seu pai". ${ }^{85}$ Entretanto, ainda não consegue perceber as causas mais profundas pelas quais o pai e os estivadores lutaram. Para o personagem, fazer parte de uma greve e sonhar com isto apresenta-se como a possibilidade de vingar a morte paterna, descarregar o ódio contra aqueles que lhe condenaram a crescer na orfandade. A partir do momento em que passa a conhecer mais de perto a realidade do candomblé de Don'Aninha, Bala não só começa a desenvolver uma nova percepção do mundo, mas também, no plano narrativo, recebe uma outra forma de tratamento, no qual sua "cor branca" sofre um gradual processo de enegrecimento. Sua imagem, assim como a de outros personagens, passa a existir no imaginário romanesco "pintada" pela cor de sua posição frente ao mundo social e cultural.

Conformado entre as duas formas, a "branca" e a "negra", de enfrentar a realidade - respectivamente representadas na história pelas figuras do padre José Pedro e a mãe-de-santo Don'Aninha -, Bala opta pela última. Através de seu entrosamento com o candomblé da mãe-de-santo, passa a compartilhar das agruras de Don'Aninha e dos negros que diariamente travam uma luta contra as forças policiais $e$ o preconceito. Ao saber que a estátua de um dos orixás havia sido roubada pela polícia e diante a indignação da mãe-de-santo,

Pedro Bala sentiu uma onda dentro de si. Os pobres não tinham nada. O padre José Pedro dizia que os pobres um dia iriam para o reino dos céus, onde Deus seria igual para

${ }^{85}$ ID., IB., p.77. 
todos. Mas a razão jovem de Pedro Bala não achava justiça naquilo. No reino do céu seriam iguais. Mas já tinham sido desiguais na terra, a balança pendia sempre para um lado. ${ }^{86}$

O catolicismo surge aos olhos de Bala destituído de qualquer nexo com sua experiência e sentimento de ódio pelo mundo. Neste universo amadiano, optar pela luta dos negros é necessariamente tomar partido por uma luta concreta e imediata contra a desigualdade e opressão dos pobres. Assim como o inverso. O sucesso da empreitada do personagem em salvar a imagem do orixá na delegacia, somente é possível por existir no imaginário romanesco pela sua cor social. Figura conhecida por liderar o maior grupo de meninos de rua da cidade, mas nunca vista pelas autoridades policiais, Pedro Bala heroicamente se deixa prender para poder ficar junto da estátua e depois fugir: "sabiam dele apenas que tinha um talho no rosto (...) mas o pensava maior do que era em verdade e também faziam idéia de que (...) devia ser mulato" ${ }^{87} \mathrm{O}$ fato do herói ser branco (fenotipicamente) não é negado, entretanto, ele é tomado como um aspecto secundário e pouco relevante, mediante esta outra raça que, existindo no plano imaginário, é socialmente atribuída. E esta é a dimensão que importa para Jorge Amado nesse período.

O mesmo efeito deformante das dimensões estritamente biológicas pela força social pode ser sentido na personagem Dora. Sua condição de menina branca e loira acaba por se desfazer quase que completamente na medida em que passa a residir no trapiche com os meninos, sofrendo a experiência da orfandade em um "surto de bexiga" na cidade. Fazendo às vezes de mãe, irmã e integrante do grupo, Dora é simbolicamente absorvida e representada mediante as experiências particulares dos meninos. Para Volta-Seca, a menina era a sua mãe, "forte e valente mulata

${ }^{86}$ ID., IB., p.87.

${ }^{87}$ ID., IB., p.91 (destaques meus). 
As cores e os gêneros da revolução

sertaneja, capaz de brigar com soldados [e] comadre de Lampião" ${ }^{88}$ Enquanto o personagem Professor, observando a cena em que "mãe" e "filho" conversavam,

apertou os olhos e viu também, em lugar de Dora, uma sertaneja forte, defendendo seu pedaço de terra contra os coronéis (...) Viu a mãe de Volta-Seca. E era o que o mulato via. Os cabelos loiros eram carapinha rala, os olhos doces eram olhos achinesados da sertaneja, o rosto grave era o rosto sombrio de da camponesa explorada. ${ }^{89}$

O verbo ser, conjugado no passado imperfeito (era), parece encerrar bem o limbo entre o que Dora apresenta de biológico (branca e loira) e social e simbólico (uma sertaneja mulata e explorada), sendo a última a imagem importante e reveladora dos sentimentos e da positividade de valores que os meninos e o narrador a revestem. De modo que, o texto deixa transparecer uma dimensão na qual ela "é" e existe enquanto constituição física e orgânica, e uma outra, em que ela "era", fruto da incorporação e apropriação simbólica efetuada a partir da relação afetiva e social que desenvolve no trapiche em que moram.

Ao mesmo tempo, não deixa de ser interessante observarmos na personagem Dora alguns procedimentos semelhantes àqueles utilizados por Jorge Amado com Lívia, em Mar Morto. Ou seja, se é simbolicamente como uma "mulata sertaneja" que Dora é incorporada ao universo afetivo do grupo é, também, simbolicamente como "um menino" que sua importância no enredo é acentuada. Isto, na medida em que passa a participar das atividades de roubos empreendidas pelos Capitães da Areia, consideradas como uma atividade exclusivamente "de homem", deslocando-se então para o campo das ocupações masculinas do romance. Para tanto, é interessante notar como esta decisão de Dora é marcada pela inversão de seu vestuário: "o vestido servia

${ }^{88}$ ID., IB., p. 158.

${ }^{89}$ ID., IB. 
de blusa [e] como ela queria ser totalmente um dos Capitães da Areia, o trocou por umas calças". ${ }^{90}$ É a partir deste momento que Dora passa a compartilhar dos valores e a ter domínio das habilidades através das quais Jorge Amado imprimiu aos Capitães da Areia o sentido de aventura, liberdade e heroicidade:

andava como eles pelas ruas, igual a um dos Capitães da Areia. Já não achava a cidade inimiga. Agora a amava também, aprendia a andar nos becos (...) a pongar nos bondes (...) Era ágil como o mais ágil (...) Quase a achavam tão valente como Pedro Bala (...) É valente como um homem. ${ }^{91}$

Neste sentido, vemos o modo como Dora, na medida em que ganha um "papel ativo" e uma posição de maior prestígio no grupo, é racializada e, ao mesmo tempo, realocada no âmbito dos valores tido como femininos e masculinos no romance. ${ }^{92}$

No entanto, se mais uma vez voltarmos à trajetória de Pedro Bala veremos que essas imagens dos personagens, construídas no encadeamento narrativo, são acompanhadas pela progressiva descoberta pelo herói de novas formas para canalizar a sua revolta e o seu ódio. Em meio a um assalto mal sucedido, acaba sendo preso e enviado para o reformatório de menores, onde descobre o real sentido da palavra liberdade. Ali, lhe é dispensado toda espécie de maus tratos e humilhações necessárias a um "tipo

\footnotetext{
${ }^{90}$ ID., IB., p.162 (destaques meus).

${ }^{91}$ ID., IB., p.163 (destaques meus).

${ }^{92}$ Como lembra Moore, "Gênero, ou melhor, a diferença marcada por gênero, passa a representar diferenças muito reais de poder entre grupo de pessoas e entre indivíduos, e em muitos contextos é construído em referência a discursos de diferenças raciais. Os idiomas de gênero e de raça são assim usados muitas vezes para ordenar diferenças de poder e/ou prestígio, com o resultado de que o poder é representado em muitos contextos como sexualizado e racializado". MOORE, Henrietta L. Fantasias de poder e fantasias de identidade: gênero, raça e violência. Cadernos Pagu (14) - corporificando gênero -, Núcleo de Estudos de Gênero - Pagu/Unicamp, 2000, p.34.
} 
As cores e os gêneros da revolução

criminoso nato [que] traz todos os estigmas do crime na face [e] não pode ser tratado como qualquer um". ${ }^{93}$ Esfolado $e$ espancado, Bala descobre que sua liberdade nas ruas não bastava. Incitado pelas histórias dos estivadores sobre a greve e o pai, percebe que seu destino é outro, como o do pai, que "morrera para mudar o destino dos doqueiros. Quando ele sair [do reformatório] será doqueiro também, lutar[á] pela liberdade, pelo sol, por água e de comer para todos". ${ }^{94}$

Aliada a esta súbita consciência de luta, junto a uma classe específica, a morte de Dora parece indicar o encaminhamento de Bala para sua efetiva militância, na medida em que perde o único sentimento de família que tivera na vida. Agora, nosso herói está desgarrado e livre para encontrar uma outra família: a proletária. A revolução proletária amadiana e sua projeção utópica do mundo sem classes são privilegiadamente, no Brasil, um grito negro de liberdade:

A revolução chamava Pedro Bala como Deus chamava Pirulito (...) É uma voz poderosa dentro dele, poderosa como a voz do mar (...) Uma voz que atravessa a cidade, que parece vir dos atabaques, que ressoam nas macumbas da religião ilegal dos negros (...) como a voz de um negro (...) Uma voz que vem de todos os pobres (...) que chama para lutar por todos (...) Voz poderosa como nenhuma outra (...) Voz de toda a cidade pobre da Bahia, voz da liberdade. ${ }^{95}$

Na revolução, Pedro Bala não só encontra sua nova família, como também deixa fluir a voz negra de sua alma que, no limite, é a voz "de todos os pobres". Alma construída e "colorida" no transcorrer de seu processo de aprendizagem, onde se cruza a dupla luta: a da religião ilegal e a da militância nos "partidos

\footnotetext{
${ }^{93}$ AmAdO, J. Capitães da Areia. Op.cit., p.173.

${ }^{94}$ ID., IB., p. 176.

${ }^{95}$ ID., IB., p.227-29 (destaques meus).
} 
ilegais". ${ }^{96}$ De modo que, como já falado em páginas atrás, as noções de raça e classe social e sua articulação nesta trinca de romances analisados (Jubiabá, Mar Morto e Capitães da Areia), antes que pares antagônicos e excludentes um ao outro, conformam elementos que existem de modo ambivalente, podendo ser compreendidas somente a partir dos feixes de relação que as comunicam $e$ as iluminam mutuamente. O "enegrecer" de Pedro Bala poderia gerar estranhamento, caso tomássemos a questão racial somente a partir do que ela denota de biológico e físico, não prestando atenção aos tons culturalizantes com que Amado "pinta" o romance e isolando-os das prerrogativas militantes $e$ proletarizantes de seu universo ficcional. Nele, a consciência de classe é pensada na sua relação imprescindível com a cultura afro-brasileira (certamente, na sua versão baiana), como um repertório simbólico capaz de fornecer as chaves para abrir as portas das mentalidades revolucionárias.

Ao analisar Jubiabá, Mar Morto e Capitães da Areia, tentei qualificar um diálogo que Jorge Amado travou com o debate sobre as relações raciais brasileira, em meados de década de 1930. Este diálogo, menos que pinçado a partir de supostas imagens ou estereótipos com relação ao negro contido nestes romances, foi esquadrinhado numa perspectiva ampla, através da qual atentouse ao aproveitamento e tratamento específicos que Amado dispensou ao seu "material etnográfico". Ou seja, romances em que o debate racial mostrou-se simbolicamente rentável $e$ literariamente expressivo da classe proletária, das massas e coletividades que sua literatura proletária procurou incorporar como personagem. Quando vistas em conjunto, estas obras discutidas no artigo, tornam-se reveladoras de como Jorge Amado, ao mobilizar um conjunto de sentidos à prática de sua

${ }^{96}$ ID., IB., p.231. 
As cores e os gêneros da revolução

arte proletária, encontrou na cultura afro-brasileira um material farto $e$ inspirador para a composição de um universo social sempre racializado, onde "a cor" de seus personagens na verdade é uma "cor política" e social. Entretanto, se por um lado esta circulação da cor entre os seus personagens assinala para posicionamentos e relações específicas no mundo social, cultural e ideológico - ou seja, Jorge Amado nos mostra as cores negras da revolução - de outro, as marcações de gênero no espaço e os deslocamentos dos personagens deixam entrever os gêneros desta mesma revolução - a representação masculinizada da atividade revolucionária e militante, assim como dos valores e habilidades nelas envolvida.

O enegrecimento a que Jorge Amado submete seus personagens, quando inscrito nas personagens "mulheres", é acompanhado de uma série de indícios que as masculinizam, apontando para a mudança de suas posições no enredo: passam a desempenhar um "papel ativo" na transformação $e$ na

${ }^{97}$ Utilizo-me aqui da expressão extremamente pertinente de Ruth Landes, em seu livro A Cidade das Mulheres, no contexto das relações raciais no Brasil: "Lá [nos Estados Unidos] um homem poderia ser torturado pela sua cor física. No Brasil isso só poderia acontecer pela sua cor política". LANDES, Ruth. A Cidade das Mulheres. Rio de Janeiro, Ed. UFRJ, 2002, p.42. Ainda, em mais uma oportunidade a antropóloga expressa sua avaliação do significado de "ser negro" na Bahia: "Quando dizem negros (...) não pretendem indicar indivíduos de determinada cor; $e$, de fato, geralmente dizem 'africanos' ou 'afro-bainos', em vez de negros que é considerado pejorativo. Mas nem 'preto', nem 'negro', nem 'africano' são usados com freqüência a pessoas desse tipo físico que ocupem posições na classe superior. A educação ou o dinheiro, isolada ou conjuntamente, retiram um indivíduo do pitoresco grupo dos "negros'". Idem, p.54. Seria interessante lembrar que, $A$ cidade das Mulheres, embora publicado apenas em 1947, constitui o resultado de suas pesquisas de campos na Bahia entre os anos de 1938 e 1939. Ruth Landes não apenas empreendeu suas pesquisas em momentos bastante recentes da publicação de Jubiabá, Mar Morto e Capitães da Areia, como também compartilhou fortemente das relações de alguns colegas bastante caros à trajetória e à obra de Jorge Amado, tais como Édison Carneiro e Aydano do Couto de Ferraz (1914-1989). Ambos com reconhecida atuação no campo de estudos sobre as relações raciais na década de 1930 no Brasil. 
sociabilidade do ambiente. Em Capitães de Areia, Dora ao lançarse às ruas e becos da cidade não apenas "levava sua navalha", como também adquiria o respeito do grupo ao portar-se pelos códigos masculinos: "Falavam da coragem de Dora, que brigara igual a um menino". ${ }^{98}$ Em contrapartida, no romance Mar Morto, se o deslocamento de Lívia ao lugar de Guma no barco não implica numa reformulação de seus atributos femininos, esta reformulação parece encontrar seus efeitos na postura de Rosa Palmeirão. Ao lado de Lívia no barco, Palmeirão "botou a navalha na saia, punhal no peito (...) Parece um homem". ${ }^{99} \mathrm{O}$ porte da navalha, a agilidade no seu manejo e a disposição para usá-la a qualquer momento parecem garantir a estas personagens um lugar de destaque que, na literatura amadiana da década de 1930, foi ocupado privilegiadamente por aqueles masculinos. Basta termos em vista José Cordeiro, em Cacau, os agitadores políticos, em Suor, Balduíno, em Jubiabá, Guma, até a sua morte, em Mar Morto, e Pedro Bala, em Capitães da Areia.

Neste sentido, acredito que os romances analisados neste artigo mostram-se como um material bastante interessante para pensarmos os modos como raça, gênero e classe social encontram-se imbricados no projeto literário do escritor. Certamente, não se trata de afirmar que Jorge Amado formulou enredos nos quais as hierarquias dos gêneros, ou mesmo "dos sexos", serviram explicitamente como elementos estruturantes destes romances. Mas sim, ressaltar como Jorge Amado, ao centralizar seus interesses nas relações entre raça/cor e classe, encontrou nas demarcações das diferenças de gênero uma série de referências, valores e atributos à sua idéia de revolução. Assim, é o negro masculinizado que emergiu enquanto representação ideal do sujeito revolucionário amadiano. O homem racializado pela cor de sua posição social $e$ a mulher enegrecida $e$ masculinizada pelas "exigências" do caráter revolucionário.

${ }^{98}$ AMADO, J. Capitães da Areia. Op.cit., p.167.

${ }^{99}$ ID. Mar Morto. Op.cit., p.222. 